\title{
sciendo
}

DOI 10.2478/sbe-2019-0024

SBE no. 14(2) 2019

\section{THE GLOBAL CRISIS AND THE SUBSIDIES TO MANUFACTURING FIRMS}

\author{
KAYA HALIL DINCER \\ Northeastern State University, USA \\ BALAS AYSE NILGUN \\ Virginia State University, USA
}

\begin{abstract}
:
The 2008-2009 global crisis has severely affected the world economy. Most national governments utilized fiscal policy measures including subsidies to reinforce and sustain their economies. In this study we examine the impact of the 2008-2009 global crisis on subsidies paid to manufacturing firms either by their governments or the European Union (i.e. EU). Our results indicate that, overall, a significantly larger proportion of firms had received subsidies after the global crisis. When we look into different subgroups, we find that firm size, female ownership, female management, and quality certification did not matter (more firms in all of these subgroups had received subsidies). On the other hand, our results demonstrate that firm type and top manager's experience level made a difference in terms of subsidies received after the crisis.
\end{abstract}

Key words: subsidy, subsidies, manufacturing, global crisis

\section{Introduction}

The 2008-2009 global crisis has severely upset the world economy. Most national governments, in order to deal with this severe global economic crisis, utilized fiscal policy measures to reinforce and sustain their economies (Brautzsch, Günther, Loose, Ludwig, \& Nulsch 2015). One of the fiscal policy measures utilized was subsidies. Subsidies are defined as "monetary of other resources that a government grants to a firm or group of firms, intended either to encourage exports or simply to facilitate the production and marketing of products at reduced prices, to help ensure the involved companies prosper" (Cavusgil, Knight \& Riesenberger 2012, p. 211).

Review of previous research reveals that most of the current research focuses on government intervention in the form of subsidies in developed countries (Zuniga-Vicente, Alonso-Borrego, Forcadell \& Galan 2014). However, such government support is even more important in emerging countries of Eastern Europe and Central Asia as these countries have less developed financial markets, which makes it difficult for firms to gain 
access to capital (Brown, Ongena, Popov \& Yeşin 2011; Mateut 2018). Government subsidies are particularly important during financial crises as firms are faced with increased market uncertainty and reduced availability of external funds (Aristei, Sterlacchini \& Venturini 2017). However, governments restrict their financial support to firms during recessionary periods due to shrinking tax income. This paper adds on to the literature on public subsidies provided to private manufacturers by focusing on emerging countries of Eastern Europe and Central Asia and by contrasting subsidies paid during the recessionary period to the period of economic recovery.

We organize the paper as follows. First, we discuss the previous literature on public subsidies given to manufacturing firms. Second, we describe the dataset utilized for this empirical study. Third, the empirical results are illustrated. In the final section we conclude with discussion of results of our study.

\section{Literature Review}

Providing subsidies to manufacturing firms has long been a practice of governments (Uchitelle 2018). Most studies in literature focused on the relationship between public subsidies and firm research and development (R\&D) activities. There is extensive research on this topic as innovativeness is essential to survival of the manufacturing firms in the global marketplace (Aristei et al. 2017). Research on this topic gave inconclusive results (Zuniga-Vicente et al. 2014). Theoretically, there is support for both views. On one hand, one could argue that public subsidies increase R\&D spending by private firms (García-Quevedo 2004). On the other hand, one could argue that public subsidies just replace the amount of private R\&D spending without increasing the level of R\&D spending. Some scholars (e.g., Capron \& Van Pottelsberghe 1997; David, Hall \& Toole 2000) found after reviewing the previous empirical research on this topic that at the firm-level analysis direct public R\&D subsidies "crowded out" or substituted private R\&D spending rather than complimenting it. In other words, when firms were given subsidies for R\&D activities they did not use private sources for R\&D activities.

The findings of the later studies contradicted this result. In a meta-analysis of 39 empirical studies García-Quevedo (2004) found "only very weak evidence" for crowding out effect. González and Pazó (2008) examined tax credit and direct subsidies to Spanish manufacturing firms using matching estimators methodology. Their empirical results indicated no evidence of total or partial crowding out effect. Public subsidies encouraged Spanish firms to increase R\&D spending. The results also revealed that some small firms performed R\&D only when they received public subsidy. Zuniga-Vicente et al. (2014) examined seventy-seven previous published studies on the effectiveness of public subsidies on R\&D of private firms. Their research indicated that the results were inconclusive. Most of the research focused on developed countries in EU and the US. Most of the studies used firm-level data rather than aggregate data. Most of the studies focused on manufacturing firms. Finally, most studies were cross-sectional rather than longitudinal and the scholars posited that the effects of subsidies might be observed after a lag. The scholars concluded that these differences were the likely cause of inconclusive results. Becker (2015) reviewed the previous literature as well, and categorized the research on 
this topic in three streams: tax credits and direct subsidies, support of university research and formation of highly-skilled human capital, and support of formal R\&D across a variety of institutions. She posited that the large body of more recent research did not support crowding-out effect of public subsidies contrary to Zuniga-Vicente et al. (2014). She argued that sample selection bias in earlier studies contributed to crowding out or substitution effect and newer econometric methodologies controlled for such bias. Aristei et al. (2017) examined the effectiveness of direct R\&D subsidies given by largest EU countries (France, Germany, Italy, Spain and the UK). The results of their firm-level study indicated no support for crowding out effect. However, the results also revealed that public subsidies did not encourage private firms to spend additional resources. This indicates that during economic downturn public subsidies provide the much needed resources for continued R\&D activities. Finally, Mateut (2018) examined the relationship between public subsidies and firm innovativeness by using 2009 survey data from BEEPS database that covered thirty emerging country markets located in Eastern Europe and Central Asia. The results of his analysis revealed that there was a positive correlation between the receipt of subsidies and firm innovativeness. This result was even more accentuated for firms with financial constraints.

\section{Data}

In this study, we employ the BEEPSIl and BEEPSIV surveys (i.e. Business Environment and Enterprise Performance Surveys), which cover businesses in Eastern Europe and Central Asia. These surveys are done by the European Bank for Reconstruction and Development and the World Bank. These surveys have been used by prior studies (e.g., Mateut 2018). Since our objective is to examine the impact of the global crisis on subsidies paid to manufacturing firms, we compare the survey answers that cover 2008 to those that cover 2013. The 2008 survey results constitute the "pre-crisis period" and the 2013 survey results constitute the "post-crisis period".

The following 29 countries are included in the 2008 survey:
"Albania, Armenia, Azerbaijan, Belarus, Bosnia and Herzegovina,
Bulgaria, Croatia, Czech Republic, Estonia, FYR Macedonia, Georgia,
Hungary, Kazakhstan, Kosovo, Kyrgyz Republic, Latvia, Lithuania,
Moldova, Mongolia, Montenegro, Poland, Romania, Serbia, Slovak
Republic, Slovenia, Tajikistan, Turkey, Ukraine, and Uzbekistan”.

The 2013 survey also included Russia but in order to be able to compare the 2008 answers to the 2013 answers, we do not include Russia in our analyses. Therefore, we compare the "pre-crisis period" results to "post-crisis period" results for the above mentioned 29 countries.

The main question that we focus on in these surveys is as follows:

"Over the last three years has this establishment received any subsidies from the national, regional or local governments or European Union sources?"

"Yes" is coded as " 1 " and "No" is coded as "2". 
The surveys also include questions on firm size, whether or not the firm is part of a larger firm, firm type, whether or not at least one owner is female, the experience level of the top manager, the gender of the top manager, and whether or not the firm has an internationally recognized quality certification.

Table 1 shows the summary statistics for years 2008 and 2013. Panel A shows the statistics for all firms in the sample. The mean value for the answers given to the main "subsidies" question in 2008 is 1.893 , while it is 1.873 in 2013. Since "Yes" is coded as "1" and "No" is coded as "2", we can conclude that there are more businesses that received subsidies in 2013 when compared to 2008.

Panel B differentiates between small, medium-sized, and larger firms (i.e. employees 5-19, employees 20-99, and employees>99) and shows the statistics for each size group in 2008 and in 2013. For all size groups, the mean values are smaller in 2013 when compared to 2008. The mean value for small firms is 1.941 in 2008 , while it is 1.904 in 2013. The mean value for medium-sized firms is 1.894 in 2008, while it is 1.868 in 2013. The mean value for larger firms is 1.835 in 2008, while it is 1.794 in 2013 . These findings indicate that for all size groups there are more businesses that received subsidies in 2013 when compared to 2008.

Panel $\mathrm{C}$ differentiates between firms that are part of a larger firm and firms that are not part of a larger firm, and illustrates the statistics for each size group in 2008 and in 2013. For both groups, the mean values are smaller in 2013 when compared to 2008 . The mean value for firms that are part of a larger firm is 1.841 in 2008, while it is 1.800 in 2013. The mean value for firms that are not part of a larger firm is 1.898 in 2008 while it is 1.879 in 2013. These findings indicate that, for both groups, there are more businesses that received subsidies in 2013 when compared to 2008.

Panel $D$ differentiates between different types of firms and presents the statistics for each size group in 2008 and in 2013. Except for "other" type of firms, the mean values are smaller in 2013 when compared to 2008. These findings indicate that, for almost all types of firms, there are more businesses that received subsidies in 2013 when compared to 2008 .

Table 1. Summary Statistics for Subsidies to Manuf. Firms over the Last 3 Years

\begin{tabular}{lcccccc}
\hline & \multicolumn{2}{c}{$\mathbf{2 0 0 8}$} & & & $\mathbf{2 0 1 3}$ & \\
\hline & $\mathbf{N}$ & Mean & Std & $\mathbf{N}$ & Mean & Std \\
\hline Panel A. All Firms & & & & & & \\
\hline all firms & 3,944 & 1.893 & 0.309 & 4,190 & 1.873 & 0.333 \\
\hline Panel B. Firm Size & & & & & & \\
\hline employees5-19 & 1,355 & 1.941 & 0.236 & 1,996 & 1.904 & 0.295 \\
employees20-99 & 1,430 & 1.894 & 0.308 & 1,363 & 1.868 & 0.339 \\
employees>99 & 1,159 & 1.835 & 0.371 & 688 & 1.794 & 0.405 \\
\hline Panel C. Part of a Larger & & & & & & \\
Firm & & & & & & \\
\hline part of a larger firm & 383 & 1.841 & 0.366 & 330 & 1.800 & 0.401 \\
not part of a larger firm & 3,561 & 1.898 & 0.302 & 3,860 & 1.879 & 0.326 \\
\hline Panel D. Firm Type & & & & & & \\
\hline shareholding firm trading & 497 & 1.895 & 0.306 & 94 & 1.851 & 0.358 \\
& & & & & &
\end{tabular}




\begin{tabular}{|c|c|c|c|c|c|c|}
\hline \multicolumn{7}{|l|}{ in the stock market } \\
\hline $\begin{array}{l}\text { shareholding firm shares } \\
\text { traded privately }\end{array}$ & 2,278 & 1.879 & 0.326 & 3,500 & 1.867 & 0.339 \\
\hline sole proprietorship & 592 & 1.943 & 0.233 & 447 & 1.917 & 0.276 \\
\hline partnership & 115 & 1.852 & 0.356 & 44 & 1.795 & 0.408 \\
\hline limited partnership & 315 & 1.902 & 0.298 & 17 & 1.882 & 0.332 \\
\hline other & 135 & 1.896 & 0.306 & 85 & 1.918 & 0.277 \\
\hline \multicolumn{7}{|l|}{ Panel E. Female Owner } \\
\hline one or more female owner & 1,600 & 1.880 & 0.325 & 1,394 & 1.857 & 0.351 \\
\hline no female owner & 2,264 & 1.904 & 0.294 & 2,725 & 1.885 & 0.319 \\
\hline \multicolumn{7}{|l|}{$\begin{array}{l}\text { Panel F. Experienced } \\
\text { Top Manager }\end{array}$} \\
\hline \multicolumn{7}{|l|}{ top manager with $0-15$} \\
\hline $\begin{array}{l}\text { years of experience } \\
\text { top manager with }>15\end{array}$ & 2,036 & 1.896 & 0.305 & 1,981 & 1.889 & 0.314 \\
\hline years of experience & 1,797 & 1.887 & 0.317 & 2,066 & 1.854 & 0.353 \\
\hline \multicolumn{7}{|l|}{ Panel G. Top Manager } \\
\hline top manager female & 620 & 1.902 & 0.298 & 689 & 1.868 & 0.339 \\
\hline top manager not female & 3,312 & 1.892 & 0.311 & 3,483 & 1.874 & 0.332 \\
\hline \multicolumn{7}{|l|}{$\begin{array}{l}\text { Panel H. Quality } \\
\text { Certification }\end{array}$} \\
\hline $\begin{array}{l}\text { firm without an intl recog. } \\
\text { quality certification } \\
\text { firm with an intl recog. }\end{array}$ & 2,476 & 1.930 & 0.256 & 2,732 & 1.918 & 0.274 \\
\hline quality certification & 1,331 & 1.828 & 0.378 & 1,340 & 1.778 & 0.416 \\
\hline
\end{tabular}

Note: "Yes" is 1, "No" is 2

Panel E differentiates between firms with at least one female owner and firms without a female owner, and displays the statistics for each size group in 2008 and in 2013. It illustrates that, for both groups of firms, the mean values are smaller in 2013 when compared to 2008. These findings reveal that, for both groups of firms, there are more businesses that received subsidies in 2013 when compared to 2008.

Panel F differentiates between firms with less experienced top managers (i.e. top managers with a total experience of 15 years or less) and firms with more experienced top managers (i.e. top manager with more than 15 years of experience), and displays the statistics for each size group in 2008 and in 2013. The statistics reveal that, for both groups of firms, the mean values are smaller in 2013 when compared to 2008. These findings indicate that, for both groups of firms, there are more businesses that received subsidies in 2013 when compared to 2008.

Panel $G$ compares firms with a female top manager and firms with a male top manager, and shows the stats for each size group in 2008 and in 2013. We are seeing that, for both groups of firms, the mean values are smaller in 2013 when compared to 2008. These findings indicate that, for both groups of firms, there are more businesses that received subsidies in 2013 when compared to 2008.

Finally, Panel $\mathrm{H}$ differentiates between firms with an internationally recognized quality certification (i.e. ISO 9000, 9002, 14000, etc.) and firms without an internationally recognized quality certification, and displays the statistics for each size group in 2008 and 
in 2013. For both groups of firms, the mean values are smaller in 2013 when compared to 2008. This difference in means demonstrates that, for both groups of firms, there are more businesses that received subsidies in 2013 when contrasted to 2008.

Figure 1 shows the trend in the subsidies paid to small, medium, and large manufacturing firms. It is important to note that since "Yes" is coded as 1 and "No" is coded as 2 , a declining trend indicates a larger portion of firms receiving subsidies. As we can see from the figure, the trend line is going down over time for all size groups (i.e. small, medium, and larger firms), meaning that all size groups experienced some increase in subsidies. The trend line for medium sized firms (i.e. firms with 20 to 99 employees) declines more slowly than the other groups, so we can conclude that the medium sized firms experienced a smaller increase in subsidies over time.

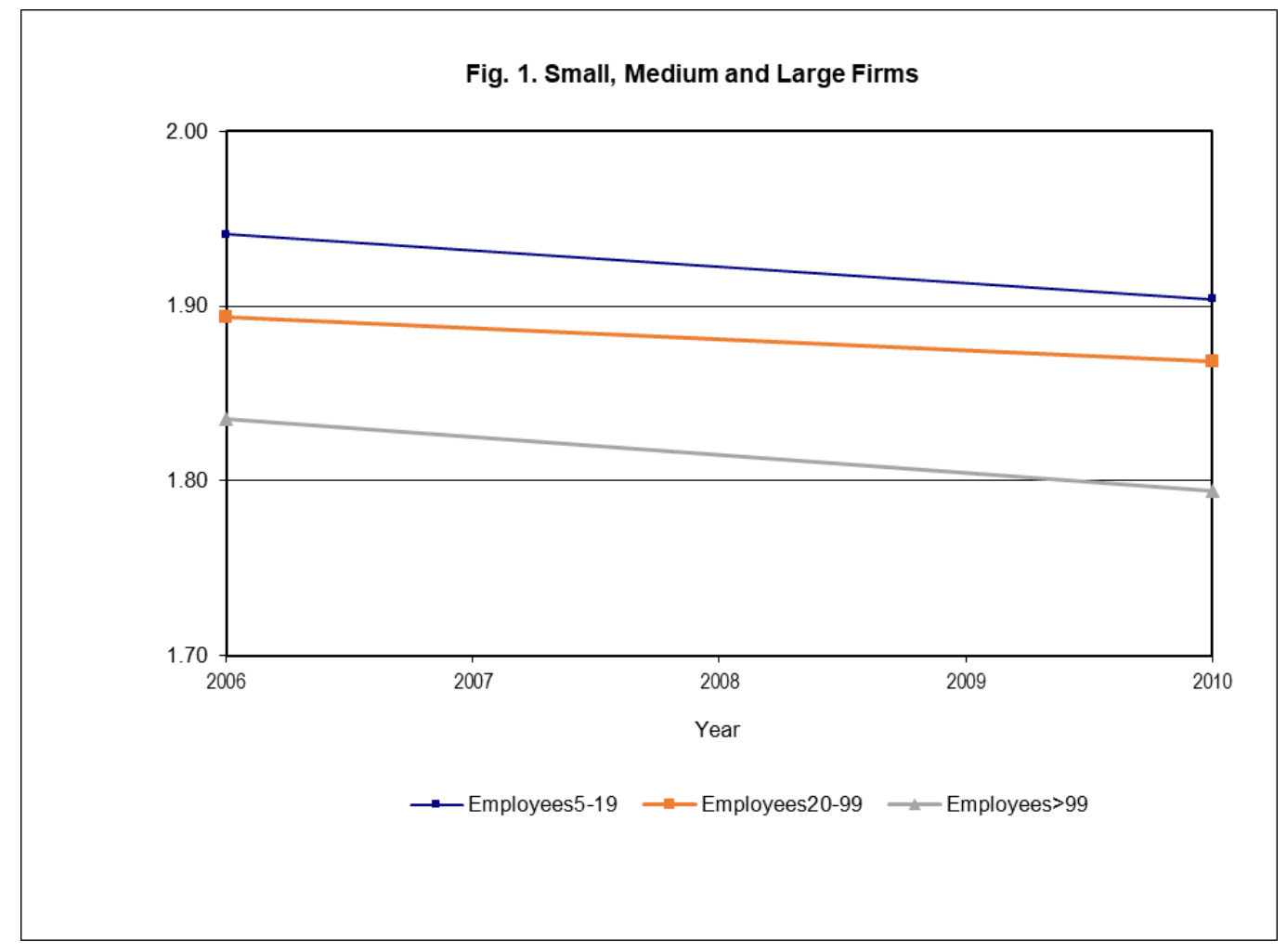

Figure 2 shows the trend in the subsidies paid to firms that are part of a larger firm (i.e. possibly more political connections) and to firms that are not part of a larger firm. Again, a declining trend indicates a larger portion of firms receiving subsidies. As we can see from the figure, the trend line is going down for both groups, meaning that both groups experienced some increase in subsidies. However, the trend line for firms that are not part of a larger firm declines more slowly than the other group, so we can conclude that the firms that are part of a larger firm experienced a larger increase in subsidies over time. This may possibly be explained by these firms' political connections and power. 
Studies in Business and Economics no. 14(2)/2019

Fig. 2. Part of a Larger Firm versus Not Part of a Larger Firm

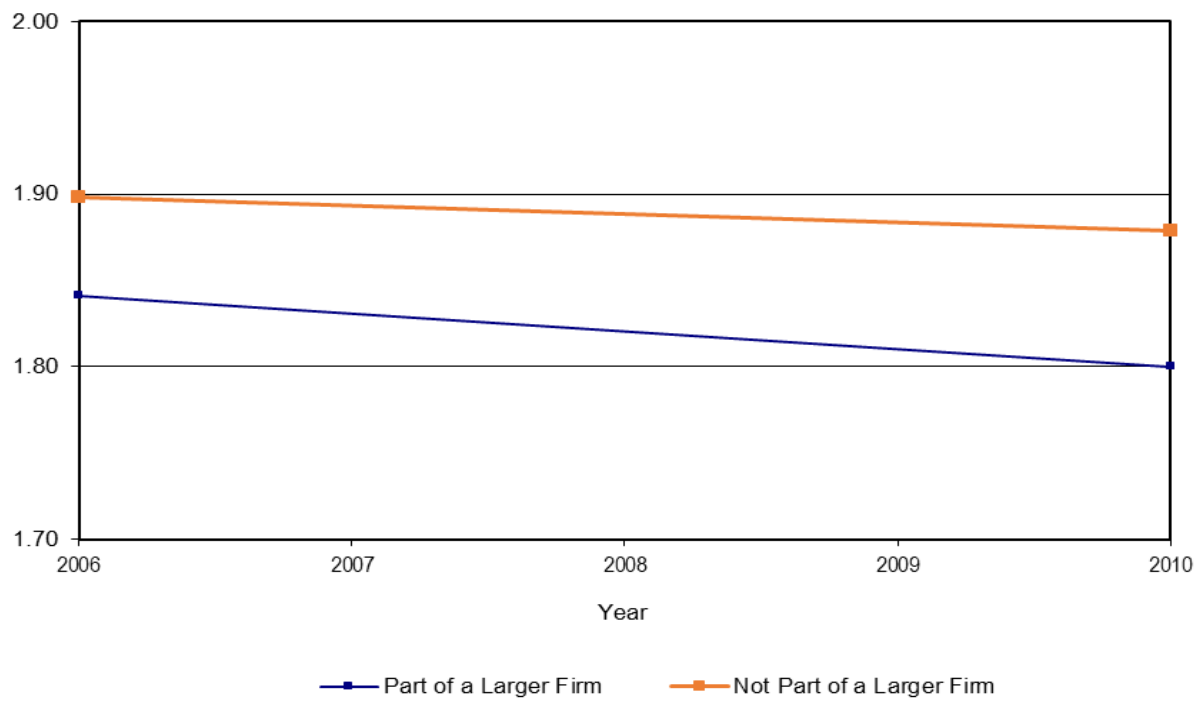

Fig. 3. Type of Firm

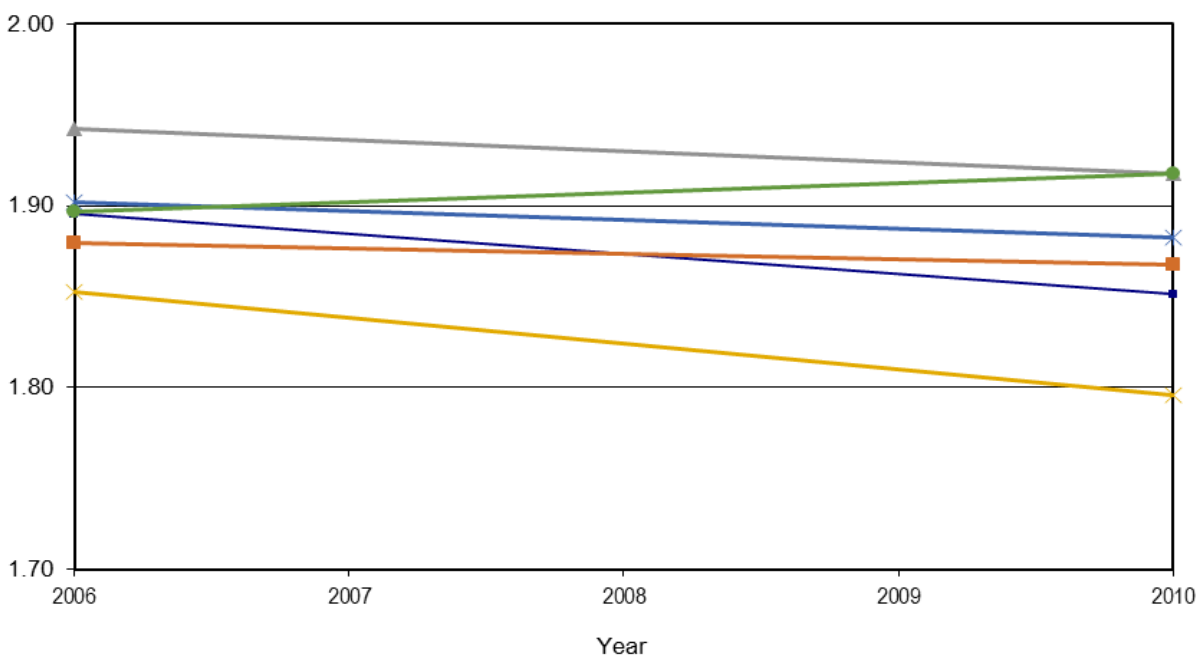

$\longrightarrow-$ Sh. Firm Tr. in the Stock Market 
Figure 3 shows the trend in the subsidies paid to different types of firms (i.e. shareholding firms with shares trading in the stock market, shareholding firms with shares traded privately, sole proprietorships, partnerships, limited partnerships, and other types of firms). As we can see from the figure, the trend line is going down for all groups (except for the "other" type of firms), meaning that they experienced some increase in subsidies. The trend line for the "other" type of firms is going up, meaning that these firms experienced a decline in subsidies.

Figure 4 shows the trend in the subsidies paid to firms that have one or more female owner and firms with no female owners. As we can see from the figure, the trend line is going down for both groups, meaning that both groups experienced some increase in subsidies. However, the trend line for firms with no female owner declines more slowly than the other group, so we can conclude that these firms experienced a smaller increase in subsidies over time. Firms with at least one female owner benefited more from subsidies over time, although the difference is very small.

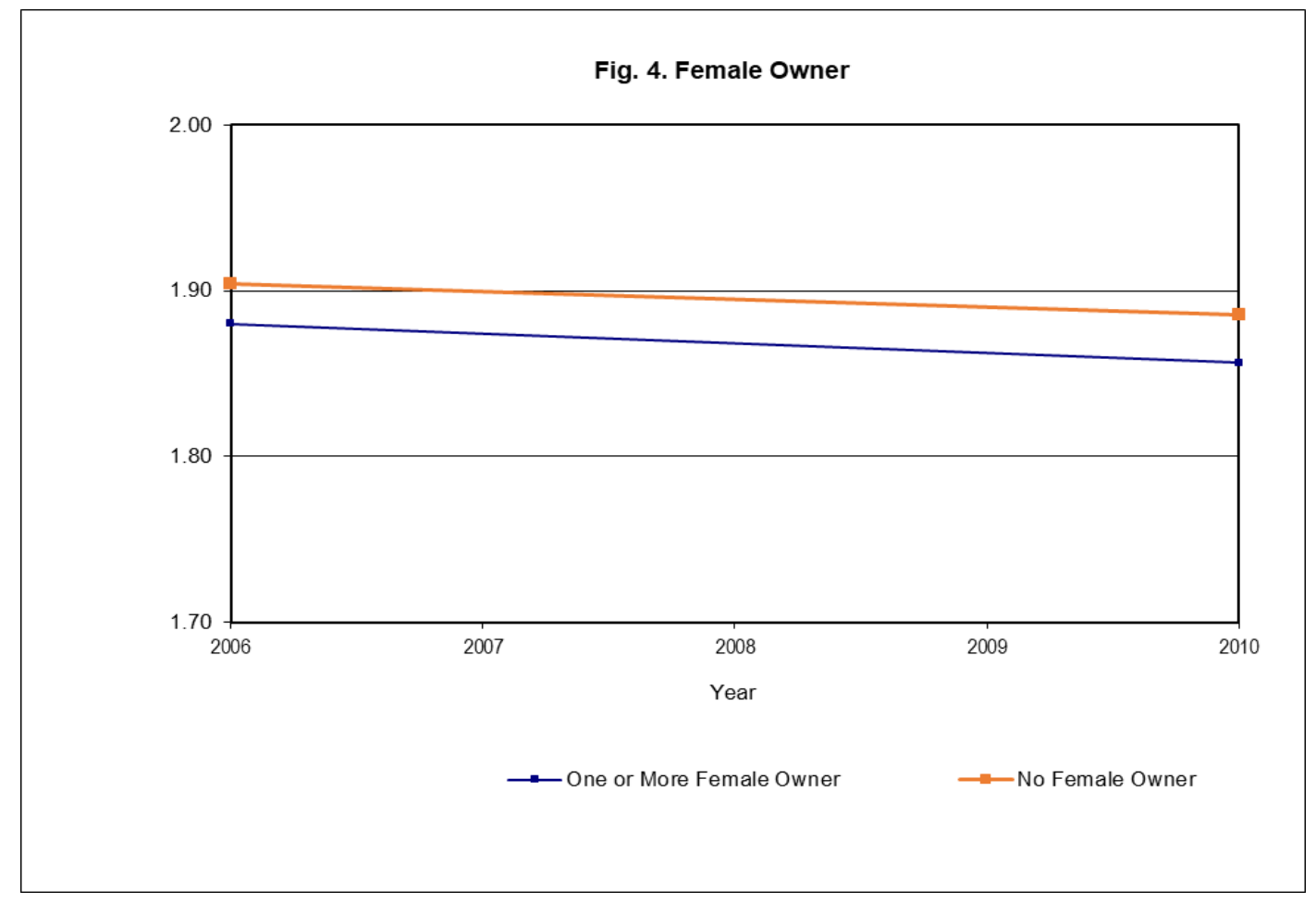

Figure 5 shows the trend in the subsidies paid to firms that have a female top manager and firms that have a male top manager. As we can see from the figure, the trend line is going down for both groups, meaning that both groups experienced some increase in subsidies. However, the trend line for firms with a male top manager declines more slowly than the other group, so we can conclude that these firms experienced a smaller increase in subsidies over time. Firms with a female top manager benefited more from subsidies over time. 
Fig. 5. Top Manager Female

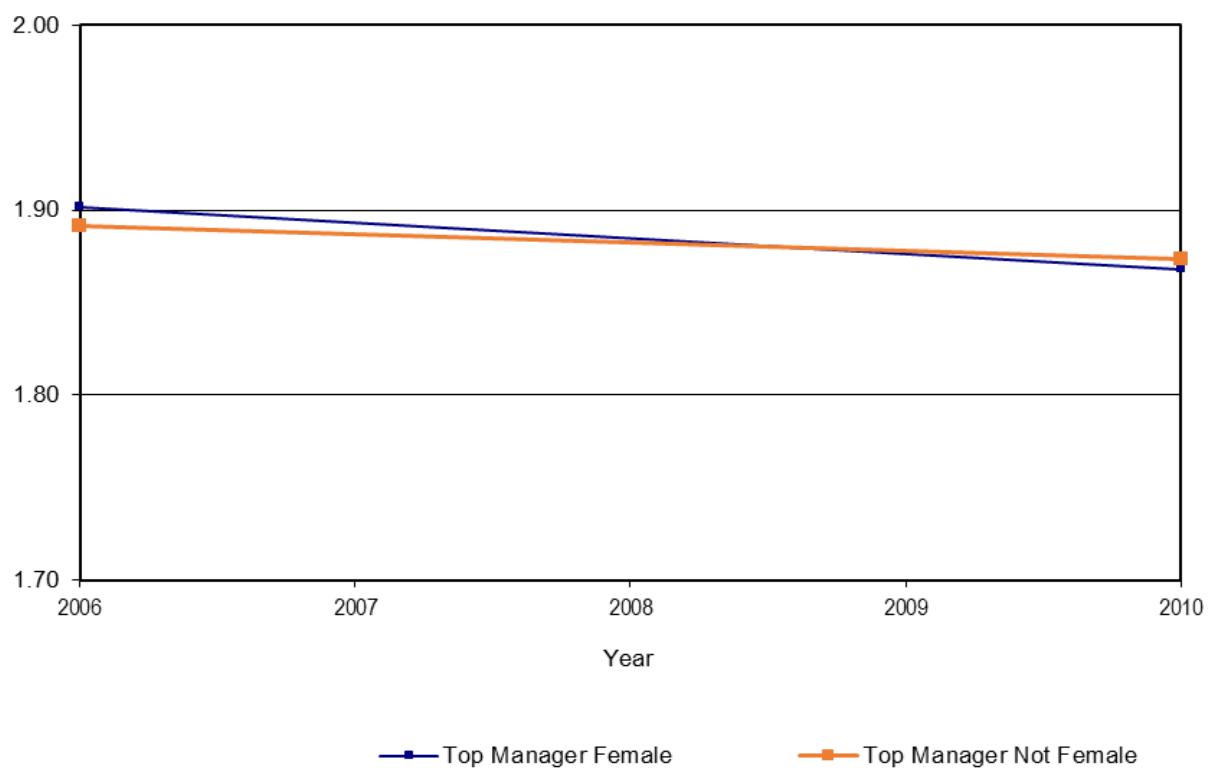

Fig. 6. Top Manager's Experience Level

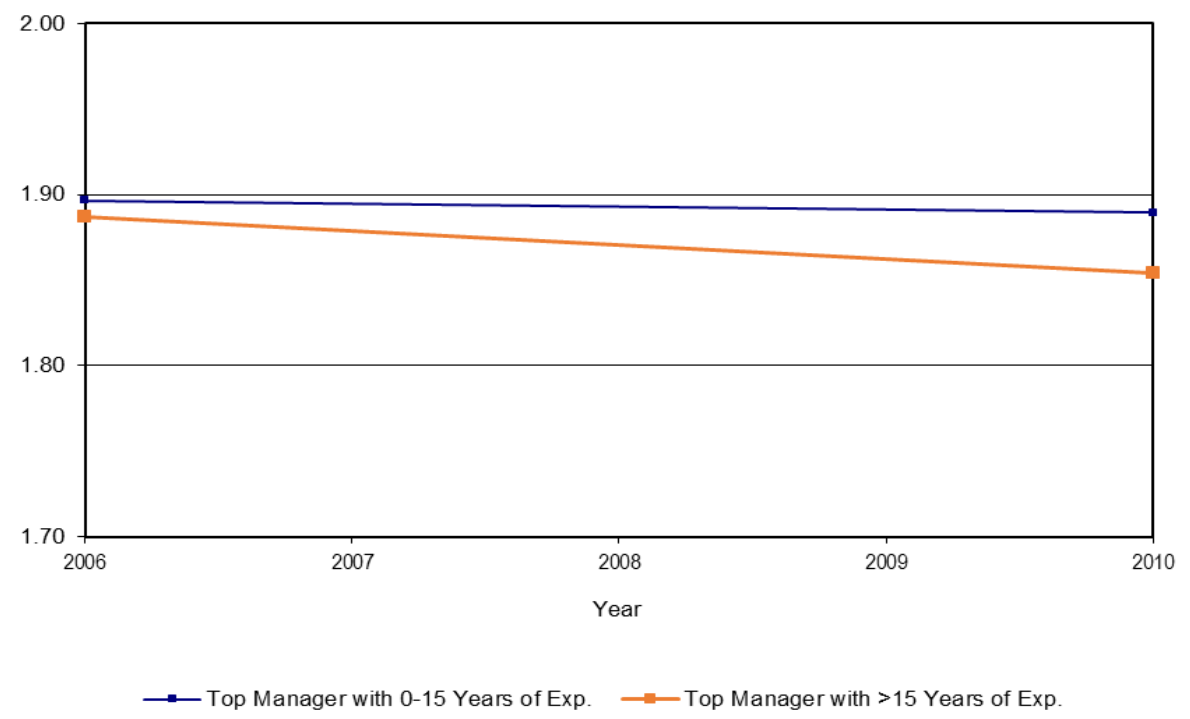


Figure 6 shows the trend in the subsidies paid to firms that have a more experienced top manager (i.e. more than 15 years of experience) and firms that have a less experienced top manager (i.e. 15 years or less). As we can see from the figure, the trend line for the firms with a less experienced top manager is almost flat, while the trend line for the other group declines. This indicates that firms with a more experienced top manager benefited more from subsidies over time.

Figure 7 shows the trend in the subsidies paid to firms that have an internationally recognized quality certification and firms that does not have an internationally recognized quality certification. The figure shows that the trend line for both groups declined meaning that both groups experienced an increase in subsidies. However, we are seeing that the firms that have an internationally recognized quality certification benefited more from subsidies over time.

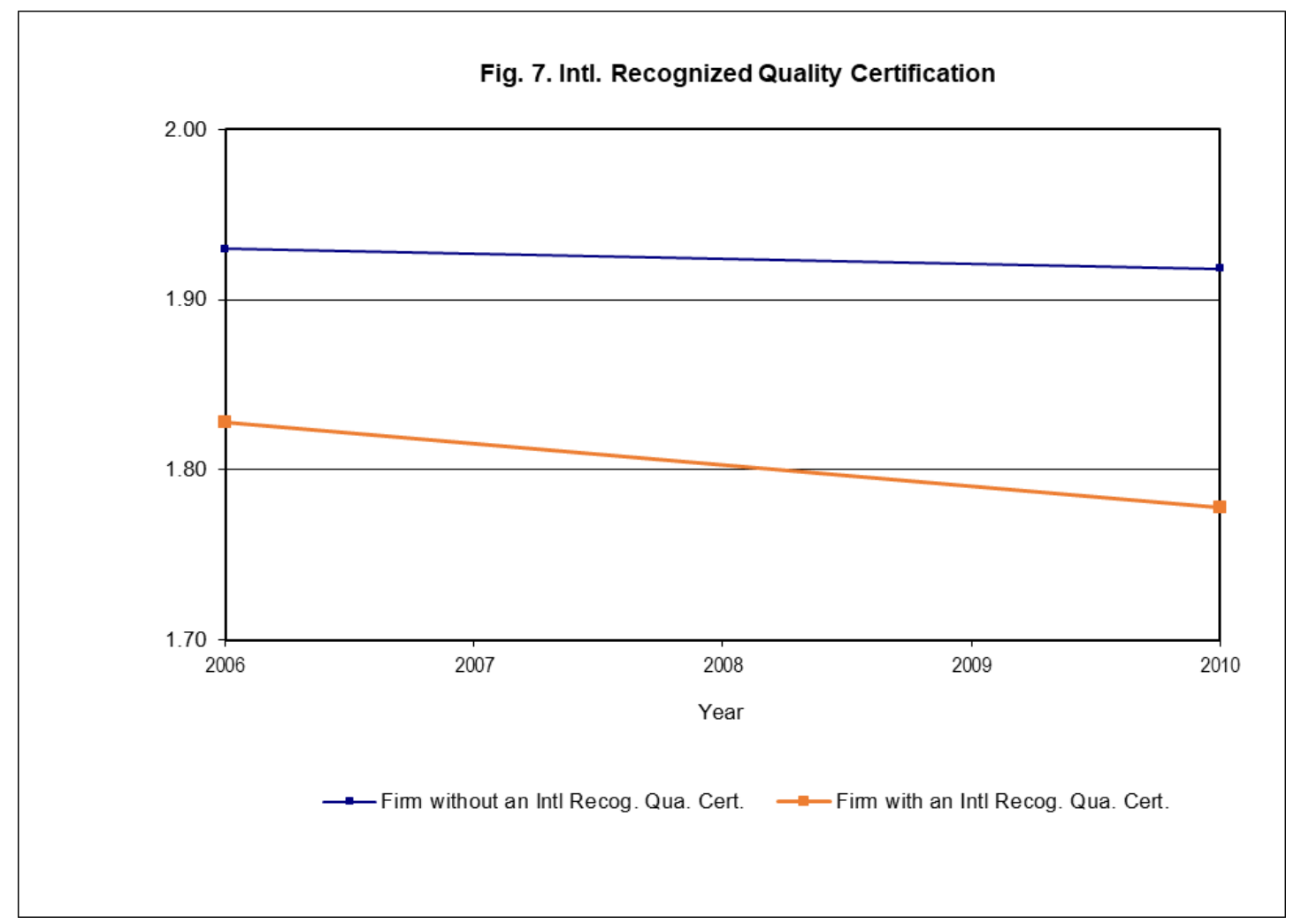

In the next section, we compare the 2008 results to the 2013 results using nonparametric tests (i.e. Mann-Whitney-Wilcoxon tests). First, we compare the results in 2008 to the results in 2013 for all sample firms. Then, we conduct comparisons for each subgroup (i.e. firm-size groups, firm-type groups, etc.).

\section{Empirical Results}


Table 2 compares the subsidies paid to all of the manufacturing firms in the sample during the three-year period ending in year 2008 versus in year 2013. The mean score is 1.893 in 2008 versus 1.873 in 2013 , meaning that there is a decline in the score. A decline in the score indicates that more firms had received subsidies from their governments or from EU in 2013 versus in 2008. The difference is statistically significant $(p=0.0026)$.

Table 2. Subsidies to Manuf. Firms over the Last 3 Years

\begin{tabular}{lllc}
\hline \multicolumn{4}{c}{ Wilcoxon Test } \\
& $\mathbf{2 0 0 8}$ & $\mathbf{2 0 1 3}$ & p-value \\
\hline all firms & 1.893 & 1.873 & 0.0026 \\
\hline
\end{tabular}

Note: "Yes" is 1, "No" is 2.

Table 3 examines whether the subsidies had increased for all firm size groups (firms with 5-19 employees, firms with 20-99 employees, and firms with more than 99 employees) and for all firm types (whether the firm is part of a larger firm and whether the firm is a shareholding firm trading in the stock market, a shareholding firm whose shares are traded privately, a sole proprietorship, etc.).

Table 3. Subsidies to Manuf. Firms (Firm Size/Type Subgroups)

\begin{tabular}{llll}
\hline & Wilcoxon Test & & \\
\hline & $\mathbf{2 0 0 8}$ & $\mathbf{2 0 1 3}$ & p-value \\
\hline employees5-19 & 1.941 & 1.904 & $<0.0001$ \\
employees20-99 & 1.894 & 1.868 & 0.0177 \\
employees>99 & 1.835 & 1.794 & 0.0123 \\
\hline part of a larger firm & 1.841 & 1.800 & 0.0784 \\
not part of a larger firm & 1.898 & 1.879 & 0.0041 \\
\hline shareholding firm trading in the stock market & 1.895 & 1.851 & 0.1058 \\
shareholding firm shares traded privately & 1.879 & 1.867 & 0.0937 \\
sole proprietorship & 1.943 & 1.917 & 0.0546 \\
partnership & 1.852 & 1.795 & 0.1951 \\
limited partnership & 1.902 & 1.882 & 0.3992 \\
other & 1.896 & 1.918 & 0.3010 \\
\hline
\end{tabular}

Note: "Yes" is 1, "No" is 2.

Our results show that all size groups (firms with 5-19 employees, firms with 20-99 employees, and firms with more than 99 employees) are affected similarly. Significantly more firms in each size group had received subsidies after the global crisis. For firms with 5-19 employees, while the mean score is 1.941 in 2008, it is 1.904 in 2013. This drop (which indicates more firms receiving subsidies) is statistically significant $(p<0.0001)$. For 
firms with 20-99 employees, while the mean score is 1.894 in 2008, it is 1.868 in 2013. This change is also statistically significant $(p=0.0177)$. For firms with more than 99 employees, while the mean score is 1.835 in 2008 , it is 1.794 in 2013 . This change is also statistically significant $(p=0.0123)$.

Table 3 also shows that it does not matter in terms of subsidies whether the firm is part of a larger firm. More firms in both groups (firms are a part of a larger firm and firms that are not a part of a larger firm) had received subsidies in 2013 compared to 2008. For firms that are part of a larger firm, while the mean score is 1.841 in 2008 , it is 1.800 in 2013. This change is statistically significant $(p=0.0784)$. For firms that are not part of a larger firm, while the mean score is 1.898 in 2008 , it is 1.879 in 2013 . This change is also statistically significant $(p=0.0041)$.

Table 3 shows that more firms with sole proprietorships and more firms with shares that are traded privately had received subsidies in 2013 when compared to 2008. For firms with sole proprietorships, while the mean score is 1.943 in 2008 , it is 1.917 in 2013. This change is statistically significant $(p=0.0546)$. For firms whose shares are traded privately, while the mean score is 1.879 in 2008 , it is 1.867 in 2013 . This change is also statistically significant $(p=0.0937)$.

On the other hand, the change in the proportion of firms receiving subsidies from 2008 to 2013 in the other groups (firms whose shares are trading in the stock market, partnerships, limited partnerships, and other firms) is not statistically significant. We can conclude that only certain types of firms had benefited during this period.

Table 4 examines whether female ownership or female managers made a difference. The results indicate that, whether the firm has a female owner or not does not matter. The proportion of firms receiving subsidies in both groups (firms with at least one female owner and firms with no female owner) had increased significantly. While the mean score for firms with one or more female owner is 1.880 in 2008 , it is 1.857 in 2013 . The difference is statistically significant $(p=0.0288)$. While the mean score for firms with no female owner is 1.904 in 2008 , it is 1.885 in 2013 . This difference is also statistically significant $(p=0.0150)$.

Table 4. Subsidies to Manuf. Firms (Female Owner/Manager)

\begin{tabular}{|c|c|c|c|}
\hline \multicolumn{4}{|c|}{ Wilcoxon Test } \\
\hline & 2008 & 2013 & p-value \\
\hline one or more female owner & 1.880 & 1.857 & 0.0288 \\
\hline no female owner & 1.904 & 1.885 & 0.0150 \\
\hline top manager female & 1.902 & 1.868 & 0.0288 \\
\hline top manager not female & 1.892 & 1.874 & 0.0109 \\
\hline
\end{tabular}

Note: "Yes" is 1, "No" is 2.

The table also demonstrates whether the firm has a female top manager or not had no difference in terms of the change in subsidies after the global crisis. The proportion of firms receiving subsidies in both groups (firms with a female top manager and firms without a female top manager) had increased significantly. While the mean score for firms 
with a female top manager is 1.902 in 2008 , it is 1.868 in 2013 . The difference is statistically significant $(p=0.0288)$. While the mean score for firms without a female top manager is 1.892 in 2008, it is 1.874 in 2013 . This difference is also statistically significant $(p=0.0109)$.

Table 5 illustrates whether top manager's experience made a difference. We are seeing that while more of the firms with an experienced top manager had received subsidies after the global crisis, we cannot say the same thing for firms with less experienced top manager. While the mean score for firms with an experienced top manager is 1.887 in 2008, it is 1.854 in 2013. The difference is statistically significant $(p=0.0013)$. On the other hand, while the mean score for firms with less experienced top manager is 1.896 in 2008, it is 1.889 in 2013 . This difference is not statistically significant $(p=0.2393)$. Therefore, we can say that while firms with more experienced top managers benefited during this period, firms with less experienced top managers did not.

Table 5. Subsidies to Manuf. Firms (Experience/Quality Subgroups)

\begin{tabular}{|c|c|c|c|}
\hline \multicolumn{4}{|c|}{ Wilcoxon Test } \\
\hline & 2008 & 2013 & p-value \\
\hline top manager with $0-15$ years of experience & 1.896 & 1.889 & 0.2393 \\
\hline top manager with $>15$ years of experience & 1.887 & 1.854 & 0.0013 \\
\hline firm without an intl recog. quality certification & 1.930 & 1.918 & 0.0560 \\
\hline firm with an intl recog. quality certification & 1.828 & 1.778 & 0.0005 \\
\hline
\end{tabular}

Note: "Yes" is 1, "No" is 2.

The table also demonstrates that, for manufacturing firms, whether the firm has an internationally recognized quality certification or not did not have importance in terms of the change in subsidies after the global crisis. The proportion of firms receiving subsidies in both groups had increased significantly. While the mean score for firms without a quality certification is 1.930 in 2008 , it is 1.918 in 2013 . The disparity is statistically significant $(p=0.0560)$. Similarly, while the mean score for firms with a quality certification is 1.828 in 2008 , it is 1.778 in 2013 . This difference is also statistically significant $(p=0.0005)$.

\section{Conclusion}

Our analysis sheds light on the comparison of government subsidies given by twenty-nine Eastern European and Central Asian countries to manufacturing firms before and after the 2008 recession. As stated before the need for government financial support is more important to manufacturing firms during recessionary periods as there is less availability of capital in capital markets. Government subsidies during recessionary periods are even more crucial for emerging markets as capital markets in emerging countries are less mature (Brown et al. 2011; Mateut 2018). However, shrinking tax income causes governments to restrict their financial support to manufacturing firms. The result of our study indicates that governments provided more subsidies to manufacturing firms after the recession. This result supports the view that government funding is scarce during times of financial crises and economic austerity (Becker 2015). This result holds true for 
manufacturing firms of all sizes, regardless of gender of the owner/manager and whether the firm had internationally recognized quality certification. However, the firms that had sole proprietorship and privately traded firms received more subsidies than publicly traded firms after the economic crisis. Further research is needed to understand the reasons behind why firms that had sole proprietorship or were privately traded received higher share of subsidies compared to other types of firms. Moreover, firms with experienced managers received more subsidies after the recession. According to the upper echelons theory executives' experience shape their understanding of the situation they face and their reaction to it (Yunlu \& Murphy 2012). Previous studies indicate that CEO's tenure determines the firms' reaction to economic recession (Cucculelli \& Bettinelli 2016).

\section{References}

Aristei, D., Sterlacchini, A. and Venturini, F. (2015), Effectiveness of R\&D subsidies during the crisis: Firm level evidence across EU countries, Economics of Innovation and New Technology, Vol. 26, No. 6, pp. 554-573.

Becker, B., (2015), Public R\&D policies and private $R \& D$ investment: $A$ survey of the empirical evidence, Journal of Economic Surveys, Vol. 29, no. 5, pp. 917-942.

Brown, M., Ongena, S., Popov, A., and Yeşin, P., (2011), Who needs credit and who gets credit in Eastern Europe?, Economic Policy, Vol. 26, no. 65, pp. 93-130.

Brautzsch, H.-U., Günther, J., Loose, B., Ludwig, U., and Nulsch, N., (2015), Can R\&D subsidies counteract the economic crisis? - Macroeconomic effects in Germany, Research Policy, Vol. 44, no. 3, pp. 623-633.

Capron, H. and Van Pottelsberghe, B., (1997), Public support to business R\&D: a survey and some new quantitative evidence in: OECD, Policy evaluation in innovation and technology. Towards best practices. Paris: Organisation for Economic Cooperation and Development, pp. $171-188$.

Cavusgil, S.T., Knight, G., and Riesenberger, J., (2012), International business: New realities (3rd edition). Pearson.

Cucculelli, M., and Bettinelli, C., (2016), Corporate governance in family firms, learning and reaction to recession: Evidence from Italy, Futures, Vol. 75, pp. 92-103.

David, P.A., Hall, B.H., and Toole, A.A., (2000), Is public R\&D a complement or substitute for private $R \& D$ ? A review of the econometric evidence,. Research Policy, Vol. 29, no. 4, pp. 497-529.

García-Quevedo, J., (2004), Do public subsidies complement business R\&D? A meta-analysis of the econometric evidence, Kyklos, Vol. 57, no. 1, pp. 87-102.

González, X. and Pazó, C., (2008), Do public subsidies stimulate private R\&D spending?, Research Policy, Vol. 37, no. 3, pp. 371-389.

Mateut, S., (2018), Subsidies, financial constraints and firm innovative activities in emerging economies, Small Business Economics, Vol. 50, no. 1, pp. 131-162.

Uchitelle, L., (2018), The case for manufacturing subsidies, Challenge, Vol. 61, no. 1, pp. 56-67.

Yunlu, D.G. and Murphy, D.D., (2012), R\&D intensity and economic recession: Investigating the moderating role of CEO characteristics, Journal of Leadership \& Organizational Studies, Vol. 19, no. 3, pp. 284-293.

Zuniga-Vicente, J.A., Alonso-Borrego, C., Forcadell, F.J., and Galan, J.I., (2014), Assessing the effect of public subsidies on firm R\&D investment: A survey, Journal of Economic Surveys, Vol. 28, no. 1, pp. 36-67. 